\title{
The Influence of Professionalism and Work Ethics of Employees on the Quality of Health Services
}

\author{
Diana Mayasari \\ Doctoral Program Student, \\ Department of Public Administration, \\ Pasundan University, Indonesia \\ Diana Gustinya \\ Doctoral Program Student, \\ Department of Accounting, \\ Pancasila University, Indonesia
}

\begin{abstract}
The purpose of this study was to determine the influence of professionalism and work ethics of employees on the quality of health services at the directorate general of railways, ministry of transportations. The formulation of the problem in this research is whether there is an effect of professionalism and work ethic of employees together on the quality of health services at the Directorate General of Railways, Ministry of Transportation. This research method uses a survey with a quantitative approach. The sampling technique used is simple random sampling. In this study, the number of samples was 72 respondents. The variables studied were professionalism (X1) and employee work ethics (X2) as independent variables, while the quality of health services was the dependent variable (Y). Based on the research results that have been done, it can be concluded that: The research results on the variables of professionalism and work ethic of employees together have a strong and significant positive influence on the quality of health services with a correlation coefficient of 0.799. While the resulting influence contribution $\left(r^{2}\right)$ is 0.638 , meaning that the variables of professionalism and employee work ethic together contribute $56.0 \%$ in influencing the health service quality variable.
\end{abstract}

Keywords: professionalism, employee work ethic, quality of health services, ministry of transportation, quantitative study

\section{Introduction}

In the current reform era, public demands for improving the quality of public services are quite reasonable and not excessive, considering that so far people still judge that the quality of public services is still not satisfactory and the performance of public services by the government is still very far from what is expected. The function of the government as a public service provider is still far from the community's expectations. 
The pattern of juraganism - asking to be served - still occurs and not the other way around. If this continues to happen without any change in the performance pattern of state employees, it is feared that it will become a mindset in the future. In the end, it will interfere with the performance of state employees in various regions. It can be felt from the slow service and the timely completion of regional development. At the same time, the spirit of regional autonomy through Law Number 23 of 2014 concerning Regional Government is increasingly open for every regional government to bring the government closer to the community so that bureaucratic pathology can be suppressed and possibly avoided. It will bring people closer to the government. Apart from bringing logical consequences, it will be clearer the responsibility of local governments to serve the community's interests. In a broad sense, the bureaucracy in public services will realize good governance.

High employee professionalism is needed to achieve public services that can satisfy the community as service users achieve satisfactory service goals. What is meant by professionalism is the ability of employees to plan, coordinate and carry out their main tasks and functions efficiently, innovatively, flexibly and have a high work ethic in providing services (Vizcarguenaga-Aguirre \& López-Robles, 2020). Therefore, employees who are truly experts in their fields are needed. The expertise of employees in their fields is obtained from the results of education and training. It can also be obtained from following the program and special experience in certain jobs. Ability to adapt to a rapidly changing environment which results in carrying out their duties and functions (Timsal \& Awais, 2016).

Employees are state apparatus or equipment, especially in the fields of institutions, management, and staffing, who have the responsibility to carry out the daily wheels of government, which show the organization's ability to use resources properly. Halim Perdana Kusuma et al. (2017) says quality is a basic business strategy that produces goods and services that explicitly and implicitly meet internal and external consumers (Piligrimienè et al., 2020). So quality usually describes a product's direct characteristics, such as performance, reliability, ease of use, aesthetics, and others. Researchers observed that the weakness in health services is the low professionalism of employees in providing services; in providing services, there is still a lack of clear information regarding service costs, unfavorable employee work attitudes, timeliness of service completion, and lack of speed employees in providing health services.

\section{Research Method}

Concerning identifying the problem above, the formulation of the research problem is as follows; Is there an influence of professionalism on the quality of health services at the Directorate General of Railways, Ministry of Transportation? Is there an influence of employee work ethics on the quality of health services at the Directorate General of Railways, Ministry of Transportation?, and Is there an effect of professionalism and work ethics of employees together on the quality of health services at the Directorate General of Railways, Ministry of Transportation? 
In this research, the author uses a survey research method with a quantitative approach, which is correlational to see how much influence the independent variable has on the dependent variable, namely the professionalism and work ethic of employees on the quality of health services. The research was conducted on individuals, namely the Directorate General of Railways, Ministry of Transportation. The population in this study were employees totaling 151 people.

In this study, the sampling technique used is simple random sampling (Creswell, 2013), which is said to be simple because the sampling of members of the population is carried out randomly without regard to the existing strata in the population. This method is carried out if the population members are considered homogeneous because the sample is representative (Vizcarguenaga-Aguirre \& López-Robles, 2020). In this study, the determination of the number of samples taken came from employees of the Directorate General using the formula (Jilcha, 2019) as follows:

$\mathrm{n}=\frac{\mathrm{N}}{\mathrm{N}(\mathrm{d})^{2}+1}$

Where:

$\mathrm{n}=$ Number of samples

$\mathrm{N} \quad=$ Total population

$\mathrm{d}=$ Set precision

It is known that the total population of employees of the Directorate General is $\mathrm{N}$ $=252$ people, and the precision level is $\mathrm{d}=10 \%$. Based on this information, the number of samples (n) is obtained as follows:

$\mathrm{n}=\frac{252}{252(0,1)^{2}+1}=\frac{252}{252(0,01)+1}=\frac{252}{3,52}=71.59$ rounding 72

Based on the above calculation, the number of samples at the Directorate General of Railways, Ministry of Transportation is 72 respondents.

\section{Theory and Concept}

In addition to work professionalism, employee work ethics are very influential in health service activities at the Directorate General of Railways, Ministry of Transportations. Ethics is one of the added values in service activities for the service user community (Paris et al., 2013). Quality services need to be supported by good attitudes and behavior from service providers (Ajzen \& Gilbert Cote, 2008). For this reason, in providing a service, a bureaucrat needs bureaucratic ethics as the basis and guidelines for acting. The application of bureaucratic ethics is carried out to serve as a moral foundation in providing effective, efficient, and professional services and the 
accountability that can influence service management to satisfy the public (Henökl, 2008).

Good governance is still an actual issue to date, especially when it is associated with the spirit of reform in terms of eradicating Corruption, Collusion, and Nepotism (Addink, 2018). It is none other than because many people still hope that the bureaucracy will show good performance and want to appear professionally in providing services. However, apart from the various problems that characterize the bureaucracy, it must be believed that making a professional bureaucracy is not easy. However, this must be done(Setyadiharja et al., 2017). Therefore, like it or not, the bureaucracy must be able to reform itself, become a professional figure with excellent service and act as a servant of the state and public servant, ready or not (Rahim, 2019).

This bureaucratic pathology causes people's perceptions to become negative about bureaucracy (Rian Andhika, 2017). Bureaucratic pathology can arise due to several things, namely the perception and managerial style of officials, lack of knowledge and skills, bureaucratic actions that violate legal norms, manifestations of dysfunctional bureaucratic behavior due to internal situations in various agencies within the government(Meier et al., 2019). This bureaucratic pathology must be observed to create a professional bureaucracy. If this continues, it will create bad governance conditions. To realize good governance that works effectively and efficiently requires work discipline from government employees where discipline relates to one's self-control against various forms of rules, both from oneself and the environment (Nugroho, 2009). Discipline is the awareness and willingness of individuals to obey all applicable rules and norms.

Improving the quality of services in the health sector at the Directorate General of Railways, Ministry of Transportations is one of the agendas that starts with the fact that the actual condition of service quality is still not maximized, which is primarily determined by the quality and attitude of government employees who are not commendable and irresponsible. Thus, the quality of health services at these institutions fulfills community needs by state administrators (Višnjić et al., 2012). However, in many cases, there are still many weaknesses in services within the organization, so that they cannot meet the quality expected by service users (Lee \& Kim, 2017). Therefore, service users still complain about the quality of services provided by employees, resulting in a bad name or image.

\section{Results and Discussion}

\section{Result}

To predict the magnitude of the influence of the independent variable on the dependent variable, the author uses the formula of determination by squaring the value of the correlation coefficient obtained R2 (Corvello et al., 2020). The influence between the variables of professionalism and work ethic of employees on the variable of the quality of health services, the following analytical calculations are used:

\section{a. Hypothesis Testing 1}

The Effect of Professionalism (X1) on the Quality of Health Services (Y) 
The hypothesis (Pernet, 2016) that the author proposes to analyze is as follows:

1) Null hypothesis (Ho): There is no positive and significant effect of the professionalism variable (X1) on the health service quality variable (Y).

2) Alternative hypothesis (Ha) (Killeen, 2005): There is a positive and significant effect of the professionalism variable (X1) on the health service quality variable (Y).

To test the hypothesis, the writer uses Product Moment analysis (Chee, 2015). The Product moment correlation will analysis formula is:

$$
r x_{1} y=\frac{\sum x_{1} y}{\sqrt{\left(\sum x_{1}{ }^{2}\right)\left(\sum y^{2}\right)}}
$$

Furthermore, to calculate the correlation value between professionalism and the quality of health services at the Directorate General of Railways, Ministry of Transportation, the calculation results are as follows:

$$
\begin{aligned}
& r x_{1} y=\frac{\sum x_{1} y}{\sqrt{\left(\sum x_{1}^{2}\right)\left(\sum y^{2}\right)}} \\
& r_{x_{1} y}=\frac{5,403}{\sqrt{(7,608)(6,912)}} \\
& r_{x_{1} y}=\frac{5,403}{\sqrt{52,591}} \\
& r_{x_{1} y}=\frac{5,403}{7,252} \\
& r_{x_{1} y}=0,745
\end{aligned}
$$

Based on the results of these calculations, the correlation coefficient found is 0.745 . After consulting this value with the previous interpretation guide table, it is known that the correlation coefficient is included in the strong positive category because it is between the interval (0.600-0.799). It shows that professionalism has a positive and strong influence on the quality of health services at the Directorate General of Railways, Ministry of Transportation. Meanwhile, to determine the contribution of professionalism to the quality of health services, the coefficient of determination (r)2 can be calculated using the following formula:

$$
\begin{array}{rlrl}
\mathrm{Kd} & = & \mathrm{r}^{2} \times 100 \% \\
= & & (0.745)^{2} \times 100 \% \\
= & 0.555 \times 100 \% \\
= & 55.5 \%
\end{array}
$$

Based on these calculations, this means that the professionalism variable of $55.5 \%$ affects the quality of health services while other factors influence the remaining $44.5 \%$. 
Furthermore, to find out whether the influence of professionalism on the quality of health services at the Directorate General of Railways, Ministry of Transportation is significant or not, it is necessary to test its significance using the $t$ formula, which is as follows:

$$
\begin{aligned}
& \mathbf{t}=\frac{\mathbf{r} \sqrt{\mathbf{n}-2}}{\sqrt{1-\mathbf{r}^{2}}} \\
& \mathrm{t}=\frac{0,745 \sqrt{72-2}}{\sqrt{1-(0,745)^{2}}} \\
& \mathrm{t}=\frac{6,234}{0,667} \\
& \mathrm{t}=9,346
\end{aligned}
$$

From the results of the calculations above, the count value is 9.346, and then this value is compared with the table value for an error of 5\%, using a two-part test where $\mathrm{dk}$ $=\mathrm{nk} ; 72-2=70$, and the table value is 2,000 . Based on the results of these calculations, the $\mathrm{t}$-count is rejected, so the alternative hypothesis (Ha) is "accepted." So the conclusion is that $t$ count falls in the area of Ha, which is the accepted hypothesis where the correlation coefficient between professionalism and the quality of health services is 0.745 , which is a strong positive and significant, meaning that the coefficient can be applied to the entire population.

b. Hypothesis Testing 2

The Effect of Employee Work Ethics (X2) towards Health Service Quality (Y). The hypothesis that the author proposes to analyze is as follows:

1) Null hypothesis (Ho): There is no positive and significant effect of employee work ethic variable (X2) on health service quality variable (Y).

2) Alternative hypothesis (Ha): There is a positive and significant effect of the employee work ethic variable (X2) on the health service quality variable (Y).

The author uses Product Moment analysis to test the hypothesis between employee work ethics on the quality of health services. The product-moment correlation analysis formula is as follows:

$$
r_{x_{2} y}=\frac{\sum x_{2} y}{\sqrt{\left(\sum x_{2}^{2}\right)\left(\sum y^{2}\right)}}
$$

To calculate the correlation value between employee work ethics and the quality of health services at the Directorate General of Railways, Ministry of Transportation, the calculation results are as follows: 


$$
\begin{aligned}
& r_{x_{2} y}=\frac{\sum x_{2} y}{\sqrt{\left(\sum x_{2}^{2}\right)\left(\sum y^{2}\right)}} \\
& r_{x_{2} y}=\frac{5,566}{\sqrt{(8,004)(6,912)}} \\
& r_{x_{2} y}=\frac{5,566}{\sqrt{55,326}} \\
& r_{x_{2} y}=\frac{5,566}{7,438} \\
& r_{x_{2} y}=0,748
\end{aligned}
$$

Based on the results of these calculations, the correlation coefficient found is 0.748 . After consulting this value with the previous interpretation guideline table, it can be seen that the correlation coefficient is included in the category of strong positive. It shows that the employee's work ethic has a strong positive influence on the quality of health services. Meanwhile, to determine the contribution of employee work ethics to the quality of health services, the coefficient of determination ( $\mathrm{r}$ )2 can be calculated using the following formula:

$$
\begin{array}{rlrl}
\mathrm{Kd} & = & \mathrm{r}^{2} \times 100 \% \\
& = & (0.748)^{2} \times 100 \% \\
= & 0.560 \times 100 \% \\
= & 56.0 \%
\end{array}
$$

Based on these calculations, this means that $56.0 \%$ of employees' work ethic variables affect the quality of health services while other factors influence the remaining $44.0 \%$. Furthermore, to find out whether the effect of employee work ethics on the quality of health services at the Directorate General of Railways, Ministry of Transportation, is significant or not, it is necessary to test its significance using the $t$ formula, which is as follows:

$$
\begin{aligned}
& t=\frac{r \sqrt{\mathbf{n}-2}}{\sqrt{1-\mathbf{r}^{2}}} \\
& \mathrm{t}=\frac{0,748 \sqrt{72-2}}{\sqrt{1-(0,748)^{2}}} \\
& \mathrm{t}=\frac{6,260}{0,663} \\
& \mathrm{t}=9,436
\end{aligned}
$$

From the calculation results, the count value is 9.436, compared with the t-table value for $5 \%$ error in the two-party test and $\mathrm{dk}=\mathrm{nk} ; 72-2=70$, and a table of 2,000 is obtained. 
Based on the results of these calculations, the t-count is rejected, so the alternative hypothesis (Ha) is "accepted." So the conclusion is that t-count falls in the area of Ha, which is the accepted hypothesis where the correlation coefficient between professionalism and the quality of health services is 0.748 , which is strongly positive and significant, meaning that the coefficient can be applied to the entire population.

c. Hypothesis Testing 3

The Effect of Professionalism (X1) and Employee Work Ethics (X2) together on the Quality of Health Services (Y).

The formulation of the hypothesis by using the multiple correlations between professionalism and work ethic of employees together on the quality of health services that the authors propose to analyze is as follows:

1) Null hypothesis (Ho): There is no positive and significant effect of the variables of professionalism (X1) and employee work ethic (X2) together on the quality of health services (Y).

2) Alternative hypothesis (Ha): There is a positive and significant effect of the professionalism variable (X1) and employee work ethic (X2) together on the quality of health services (Y).

Meanwhile, before doing the double correlation hypothesis test between professionalism (X1) and employee work ethics (X2) together on the quality of health services (Y), then first calculate the correlation between professionalism (X1) and employee work ethics (X2), with formula as follows:

$$
\begin{aligned}
\operatorname{rx} 1 \times 2 & =\frac{\sum x_{1} x_{2}}{\sqrt{\left(\sum x_{1}^{2}\right)\left(\sum x_{2}{ }^{2}\right)}} \\
& =\frac{5,825}{\sqrt{(7,608)(8,004)}} \\
& =\frac{5,825}{\sqrt{60,896}} \\
& =5,825 \\
& =0,804
\end{aligned}
$$

Furthermore, to test the dual correlation between professionalism (X1) and employee work ethics (X2) together on the quality of health services (Y) at the Directorate General of Railways, Ministry of Transportation, it can be calculated by the following formula: 


$$
\begin{aligned}
& R x_{1} x_{2} y=\sqrt{\frac{r_{x_{1} y}{ }^{2}+r_{x_{2} y}{ }^{2}-2 r_{x_{1} y} \cdot r_{x_{2} y} \cdot r_{x_{1} x_{2}}}{1-r_{x_{1} x_{2}}{ }^{2}}} R_{X_{1} X_{2 y} y}=\sqrt{\frac{(0,745)^{2}+(0,748)^{2}-2 \cdot(0,745) \cdot(0,748) \cdot(0,746)}{1-(0,746)^{2}}} \\
& R_{X_{1} X_{2} y}=\sqrt{\frac{(0,555)+(0,560)-0,832}{1-0,557}} \\
& R_{X_{1} X_{2} y}=\sqrt{\frac{1,115-0,832}{0,443}} \\
& R_{X_{1} X_{2} y}=\sqrt{\frac{0,283}{0,443}} \\
& R_{X_{1} X_{2} y}=\sqrt{0,638} \\
& R_{X_{1} X_{2} y}=0,799
\end{aligned}
$$

Based on the results of these calculations, the multiple correlation coefficient found is 0.799 . After consulting the previous interpretation guide table for this value, it is known that the multiple correlation coefficient is included in the strong category. It shows that employees' professionalism and work ethic have a strong positive influence on the quality of health services at the Directorate General of Railways, Ministry of Transportation. This effect applies to the entire population.

To predict the magnitude of the influence between professionalism and work ethics of employees together on the quality of health services, the Directorate General of Railways, Ministry of Transportation, is carried out by calculating the coefficient of determination, namely the formula squaring the value of the correlation coefficient (r2) below:

$$
\begin{array}{rlrl}
\mathrm{Kd} & = & \mathrm{r}^{2} \times 100 \% \\
= & & (0.799)^{2} \times 100 \% \\
= & 0.638 \times 100 \% \\
= & 63.8 \%
\end{array}
$$

It means that the variables of professionalism and work ethic of employees of $63.8 \%$ together affect the quality of health services, and other factors influence the remaining 36.2\%. Furthermore, to test the significance of the double correlation of professionalism and employee work ethic on the quality of health services, the researchers conducted a test by determining the F-count value, which was consulted with the F-table value, with the following formula:

$$
\begin{aligned}
& \mathrm{F}_{\text {hit }}=\frac{\mathrm{R}^{2} / \mathrm{k}}{\left(1-\mathrm{R}^{2}\right) /(\mathrm{n}-\mathrm{k}-1)} \\
& \mathrm{F}=\frac{(0,799)^{2} / 2}{\left(1-0,799^{2}\right) /(72-2-1)} \\
& \mathrm{F}=\frac{0,319}{0,362 / 69}
\end{aligned}
$$


$\mathrm{F}=\frac{0,319}{0,005}$

$\mathrm{F}=60,927$

So the obtained Fount value of 60.927 , this value is then consulted with Ftable, for DK numerator $=2$ and dk denominator $=(72-2-1)=69$, obtained Ftable value at the set error level is $5 \%=3.13$. In this case, the provisions apply if Fount is greater than Ftable, then the multiple correlation coefficient tested is significant; that is, it can apply to the entire population. From the above calculation, it turns out that Fount $>$ Ftable $(60.927>3.13$ ) shows that the multiple correlations are strong, positive, and significant and can be applied where the sample is taken. Moreover, a hypothesis that reads:

d. Multiple Regression Analysis

Multiple regression analysis (Denis, 2018) was used to predict how much change in the independent variables professionalism and employee work ethic to the dependent variable quality of health services at the Directorate General of Railways, Ministry of Transportation. Where the multiple regression analysis has expressed the equation:

$=\mathrm{a}+\mathrm{b} 1 \mathrm{X} 1+\mathrm{b} 2 \mathrm{X} 2$

With the following formula:

$$
\begin{aligned}
b_{1} & =\frac{\left(\sum x_{1} y\right)\left(\sum x_{2}^{2}\right)-\left(\sum x_{1} x_{2}\right)\left(\sum x_{2} y\right)}{\left(\sum x_{1}{ }^{2}\right)\left(\sum x_{2}^{2}\right)-\left(\sum x_{1} x_{2}\right)^{2}} b_{2}=\frac{\left(\sum x_{2} y\right)\left(\sum x_{1}^{2}\right)-\left(\sum x_{1} x_{2}\right)\left(\sum x_{1} y\right)}{\left(\sum x_{1}{ }^{2}\right)\left(\sum x_{2}{ }^{2}\right)-\left(\sum x_{1} x_{2}\right)^{2}} \\
a & =\frac{\sum Y-b_{1}\left(\sum X_{1}\right)-b_{2}\left(\sum X_{2}\right)}{n}
\end{aligned}
$$

From the helper table to calculate the multiple regression equation two predictors are obtained:

$$
\begin{aligned}
& \Sigma X 1=287,400 \Sigma X 12=1154,813 \\
& \Sigma X 1 \cdot Y=1158,729 \\
& \Sigma X 2=291,000 \Sigma X 22=1184 \cdot 129 \\
& \Sigma X 2 \cdot Y=1173 \cdot 338 \\
& \Sigma Y \quad=288,933 \Sigma Y 2 \quad=1166,391 \\
& \Sigma X 1 \cdot X 2=1167,400
\end{aligned}
$$

Where:

$$
\begin{array}{rlr}
\Sigma x 1^{2} & = & \Sigma X 12-(\Sigma X 1) 2 / \mathrm{n} \\
& = & 1154,813-\frac{(287,400)^{2}}{72} \\
& = & 1154,813-\frac{82598,760}{72} \\
& = & 1154,813-1147,205 \\
& = & 7,608
\end{array}
$$




$$
\begin{array}{rlr}
\Sigma x 2^{2} & = & \Sigma X 22-(\Sigma X 2) 2 / \mathrm{n} \\
& = & 1184,129-\frac{(291,000)^{2}}{72} \\
& = & 1184,129-\frac{84681,000}{72} \\
& = & 1184,129-1176,125 \\
& = & 8.004 \\
\Sigma y^{2} & = & \Sigma Y 2-(\Sigma Y) 2 / \mathrm{n} \\
& & 1166,391-\frac{(288,933)^{2}}{72} \\
& = & 1166,391-\frac{83482,471}{72} \\
& = & 1166,391-1159,479 \\
& = & 6,912
\end{array}
$$

$$
\begin{aligned}
& \Sigma x 1 . x 2=\quad \Sigma X 1 . X 2-\frac{\left(\Sigma \mathrm{X}_{1}\right) \cdot\left(\Sigma \mathrm{X}_{2}\right)}{\mathrm{n}} \\
& =1167,400-\frac{(287,400)(291,000)}{72} \\
& =\quad 1167,400-\frac{83633,400}{72} \\
& =1167,400-1161,575 \\
& =\quad 5,825
\end{aligned}
$$

$$
\begin{aligned}
& \Sigma \mathrm{x} 1 . \mathrm{y}=\quad \sum \mathrm{X} 1 \mathrm{Y}-\frac{\left(\sum \mathrm{X}_{1}\right) \cdot\left(\sum \mathrm{Y}\right)}{\mathrm{n}} \\
& =\quad 1158,729-\frac{(287,400)(288,933)}{72} \\
& =\quad 1158,729-\frac{83039,440}{72} \\
& =1158,729-1153,326 \\
& =5,403 \\
& \Sigma \mathrm{x} 2 \mathrm{y}=\quad \Sigma \mathrm{X} 2 . \mathrm{Y}-\frac{\left(\Sigma \mathrm{X}_{2}\right) \cdot(\Sigma \mathrm{Y})}{\mathrm{n}} \\
& =\quad 1173,338-\frac{(291,000)(288,933)}{72} \\
& =\quad 1173,338-\frac{84079,600}{72} \\
& =1173,338-1167,772 \\
& =\quad 5.566
\end{aligned}
$$


Furthermore, to calculate the prices or values of constants (a), b1, and b2, the calculation is done with the following formula:

$$
\begin{aligned}
& b_{1}=\frac{\left(\sum x_{1} y\right)\left(\sum x_{2}^{2}\right)-\left(\sum x_{1} x_{2}\right)\left(\sum x_{2} y\right)}{\left(\sum x_{1}^{2}\right)\left(\sum x_{2}^{2}\right)-\left(\sum x_{1} x_{2}\right)^{2}} \\
& \frac{(5,403) \cdot(8,004)-(5,825) \cdot(5,566)}{(7,608) \cdot(8,004)-(5,825)^{2}} \\
& =\frac{43,248-32,419}{60,896-33,931} \\
& =\frac{10,828}{26,966} \\
& =0.402 \\
& b_{2}=\frac{\left(\sum x_{2} y\right)\left(\sum x_{1}^{2}\right)-\left(\sum x_{1} x_{2}\right)\left(\sum x_{1} y\right)}{\left(\sum x_{1}{ }^{2}\right)\left(\sum x_{2}^{2}\right)-\left(\sum x_{1} x_{2}\right)^{2}} \\
& \frac{(5,566) \cdot(7,608)-(5,825) \cdot(5,403)}{(7,608) \cdot(8,004)-(5,825)^{2}} \\
& =\frac{42,345-31,474}{60,896-33,931} \\
& =\frac{10,870}{26,966} \\
& =\quad 0.403 \\
& \begin{array}{ll} 
& \frac{\sum Y-b_{1}\left(\sum X_{1}\right)-b_{2}\left(\sum X_{2}\right)}{n} \\
\mathrm{a} \quad & \frac{288,933-0,402(287,400)-0,403(291,000)}{72} \\
= & \frac{288,933-115,408-117,306}{72} \\
= & \frac{56,219}{72} \\
= & 0.781
\end{array}
\end{aligned}
$$

Based on the results of these calculations obtained:

$\begin{array}{lll}\mathrm{a} & = & 0.781 \\ \mathrm{~b} 1 & = & 0.402 \\ \mathrm{~b} 2 & = & 0.403\end{array}$


From the value of the constant a and the regression coefficients b1 and b2, the regression equation can be made:

$$
\begin{array}{ll}
= & a+b_{1} \mathrm{X} 1+\mathrm{b} 2 \mathrm{X} 2 \\
= & 0.781+0.402 \mathrm{X}_{1}+0.403 \mathrm{X} 2
\end{array}
$$

The regression equation of professionalism and work ethics of employees together on the quality of health services are $=0.781+0.402 \mathrm{X} 1+0.403 \mathrm{X} 2$. It means that the quality of health services is high and low because professionalism and work motivation can be predicted through the regression equation. Based on these data, employees' highest professionalism and work ethic scores are 75 ( $5 \times 15) .5$ is the highest score for each answer, and 15 is the number of question items. Therefore, the value of improving the quality of health services is:

$$
\begin{aligned}
& =0.781+0.402+0.403 .75 \\
& =0.781+60.350 \\
& =61,131
\end{aligned}
$$

If the value of professionalism and work ethic of employees is increased to 75 units, then the value of the quality of health services increases from 0.781 units to 61.131 units. Therefore, it means that the higher the professionalism and the better the employees' work ethic, the higher the quality of health services at the Directorate General of Railways, Ministry of Transportation.

\section{Discussion and Analysis}

Based on the proposed hypothesis about the effect of professionalism and work ethic of employees on the quality of health services at the Directorate General of Railways, Ministry of Transportation, it is necessary to discuss the existence of each variable. The research results on the professionalism variable have a strong and significant positive influence with a correlation coefficient value of 0.745 , while the coefficient of determination $\left(\mathrm{r}^{2}\right)$ is 0.555 , meaning that the professionalism variable contributes $55.5 \%$ in influencing the health service quality variable. While the t-test value of 9.346 is greater than the t-table of 2,000 so it can be concluded that the null hypothesis (Ho), which states that there is no positive and significant effect between professionalism on the quality of health services, is "rejected" and the alternative hypothesis (Ha) which states there is a positive and significant influence between professionalism on the quality of health services "accepted." Although the effect between these two variables is strong and significant, with a coefficient of determination that is only $55.5 \%$, it shows that the professionalism of employees is not maximized. It needs to be improved by increasing the professionalism of employees through organizing training for employees who lack good work skills, establishing character building for all employees by participating in seminars held by the agency, and maximizing and channeling the potential of employees in the fields under their control. 
The results of the research on the employee work ethic variable have a strong and significant positive influence on the quality of health services with a correlation coefficient value of 0.748 , while the coefficient of determination $\left(\mathrm{r}^{2}\right)$ is 0.560 , meaning that the employee work ethic variable contributes $56.0 \%$ in influencing the quality variable-health services. The t-test value of 9.436 is greater than the t-table $(2,000)$, so it can be concluded that the null hypothesis (Ho) is rejected, and the alternative hypothesis (Ha) is accepted. Although the effect between these two variables is strong and significant, the coefficient of determination which is only $56.0 \%$, shows that the employee's work ethic in terms of service has not satisfied service users.

It needs to be changed by improving employees' work ethic by providing rewards and punishments for employees with the status of State Civil Apparatus and Non-State Civil Apparatus in terms of service to service users in the relevant agency. In addition, policies that exist within the organization must also pay attention to the needs and interests of employees, especially those who serve as service officers, because by accommodating and paying attention to the interests of service officers, employees will not behave and have bad ethics in carrying out their duties. However, with a coefficient of determination of only $56.0 \%$, employees' work ethic in terms of service has not satisfied service users. Therefore, it needs to be changed by improving employees' work ethic by providing rewards and punishments for employees with State Civil Apparatus and Non-State Civil Apparatus in terms of service to service users in the relevant agency. In addition, policies that exist within the organization must also pay attention to the needs and interests of employees, especially those who serve as service officers, because by accommodating and paying attention to the interests of service officers, employees will not behave and have bad ethics in carrying out their duties. However, with a coefficient of determination of only $56.0 \%$, employees' work ethic in terms of service has not satisfied service users.

The results of the simultaneous analysis show that the professionalism and work ethic of employees have a strong and significant positive effect on the quality of health services. It has been significantly proven from the results of research partially and simultaneously that the quality of health services at the Directorate General of Railways, Ministry of Transportation can be determined by factors of professionalism and work ethic of employees as seen from the correlation coefficient value of 0.799 . At the same time, the resulting influence contribution $\left(\mathrm{r}^{2}\right)$ is $63.8 \%$, and other factors outside the research model determine the remaining $36.2 \%$. The results of the calculated $F$ test of the three variables showed the results of 60,927 , which is greater than the F table $(3,13)$. Therefore, it can be interpreted that there is no positive and significant effect of employees' professionalism and work ethic on the quality of health services. Therefore, $\mathrm{h}$ null is rejected, and the alternative hypothesis (Ha) is accepted.

The resulting influence between these three variables is strong and significant, with a coefficient of determination of $63.8 \%$. However, with the remaining determination of $36.2 \%$, it shows that employees' professionalism and work ethic have not improved the quality of service to the maximum. Therefore, it needs to be improved by providing creative and innovative services to realize excellent service and customer satisfaction. Creative and innovative services in the form of the latest strategies to facilitate and expedite the fulfillment of both public and community services, such as online 
technology-based services (making special applications for health services in the form of websites, for example, e-regulation, e-health service, e-information) so that customers can access information easily and quickly.

Based on the preceding, the variables of professionalism and work ethic of employees on the quality of health services indicate that the magnitude of the influence of the variables quantitatively can be explained as follows:

a) The author needs to analyze the influence of the variable X1 (professionalism) on $Y$ (quality of health services) because professionalism is a commitment to producing quality work based on the expertise possessed by a person to bring satisfaction to others. People who are called professionals commit (a very responsible behavior or attitude) in carrying out their profession or also called having integrity. Professionalism is always associated with efficiency and effectiveness, which is indicated by expertise (competence), commitment (integrity), and output (output).

b) For the effect of the variable X2 (employee work ethic) on Y (quality of health services), the authors need to analyze because the employee's work ethic is a critical and rational reflection on moral values, ethical codes, and moral norms as well as the science of good behavior and moral philosophy. that determine and manifest in attitudes and patterns of human behavior, both individually and in groups

c) Finally, this study will prove the influence of the variable professionalism (X) and employee work ethic (X2) on the variable quality of health services (Y). The variable quality of health services is measured by a reliable attitude, has a fast response, provides self-confidence and empathy for service users, and tangible services to provide satisfaction to the service user community with predetermined standards.

Identifying the variables of professionalism and work ethic of employees will affect the quality of health services. According to the author, based on the above thinking, the hypothesis states that professionalism and work ethic of employees has a strong influence on the quality of health services at the Directorate General of Railways, Ministry of Transportation, is acceptable. Furthermore, the magnitude of the influence of the two independent variables with the dependent variable also shows how to implement and improve the quality of health services optimally; this fact has been answered by the existence of high professionalism and good employee work ethics.

Practically, the two variables work together, meaning that in the process, employees' professionalism and work ethic can become variables or factors that determine whether the quality of health services is high or low. If professionalism is high and employees' work ethic is good, then the quality of health services will automatically increase. In this discussion, the author concludes that the two independent variables above show a very significant influence, meaning that without high professionalism and good employee work ethics, the quality of health services at the Directorate General cannot be achieved improved or implemented optimally. 


\section{Conclusion and Recommendation}

Conclusion: The research results on the professionalism variable have a strong and significant positive effect with a correlation coefficient of 0.745 . While the value of the coefficient of determination $\left(\mathrm{r}^{2}\right)$ is 0.555 , meaning that the professionalism variable contributes $55.5 \%$ in influencing the health service quality variable. The research results on the employee work ethic variable have a strong and significant positive influence on the quality of health services with a correlation coefficient of 0.748 . While the value of the coefficient of determination $\left(\mathrm{r}^{2}\right)$ is 0.560 , meaning that the employee work ethic variable contributes $56.0 \%$ in influencing the health service quality variable. The results of the research that the variables of professionalism and work ethic of employees together have a strong and significant positive influence on the quality of health services with a correlation coefficient of 0.799 . While the resulting influence contribution $\left(r^{2}\right)$ is 0.638 , meaning that the variables of professionalism and work ethic of employees contribute $56.0 \%$ in influencing the variable quality of health services.

Recommendation: the professionalism of employees in the service and health sector needs to be improved immediately, the need for supervisory monitoring to provide high work results, and improve skills through quality training. Employees who lack good work skills establish character building for all employees by participating in seminars held by the agency and maximizing and channeling employees' potential in the fields under their control. The work ethic of employees at the Directorate General of Railways, Ministry of Transportation, is suggested to be improved by implementing moral norms and social sanctions for employees who violate regulations, seriously increasing compliance with applicable legal rules within the organization, improving work ethics employees through rewards and punishments for employees with the status of State Civil Apparatus and Non-State Civil Apparatus in terms of service to service users in the relevant agency. In addition, existing policies within the organization must also pay attention to the needs and interests of employees, especially those who serve as service officers. The quality of health services at the Directorate General of Railways, Ministry of Transportation is suggested to be improved through creative and innovative services so that excellent service is realized and is customer satisfaction oriented. Creative and innovative services in the form of the latest strategies to facilitate and expedite the fulfillment of both public and community services, such as online technology-based services (making special applications for health services in the form of websites, for example, e-regulation, e-health service, e-information).

\section{References}

Addink, G. H. (2018). Good Governance: Importance in Practice, Theories, and Definitions. Halu Oleo Law Review, 1(1), 1. https://doi.org/10.33561/holrev.v1i1.2347

Ajzen, I., \& Gilbert Cote, N. (2008). Attitudes and the prediction of behavior. In Attitudes and Attitude Change (pp. 289-311).

Chee, J. (2015). Pearson's Product-Moment Correlation: Sample Analysis. https://doi.org/10.13140/RG.2.1.1856.2726 
Corvello, V., Chimenti, M. C., Giglio, C., \& Verteramo, S. (2020). An investigation on the use by academic researchers of knowledge from scientific, social networking sites. Sustainability (Switzerland), 12(22), 1-16. https://doi.org/10.3390/su12229732

Creswell, J. W. (2013). Qualitative inquiry \& research design: Choosing among five approaches, in Sage (1st ed.). Pustaka Pelajar, Indonesia.

Denis, D. (2018). Simple and Multiple Linear Regression (pp. 103-130). https://doi.org/10.1002/9781119465775.ch9

Halim Perdana Kusuma, A., Said, S., \& Hasan, S. (2017). The implication of External and Internal Factors of Mall Consumers in Indonesia to Impulsive Buying Behavior. International Journal of Business, Accounting, and Management, 2.

Henökl, T. (2008). What are Public Services Good at? The success of Public Services in the Field of Human Resource Management.

Jilcha, K. (2019). Research Design and Methodology (p. 27). https://doi.org/10.5772/intechopen.85731

Killeen, P. (2005). An Alternative to Null-Hypothesis Significance Tests. Psychological Science, 16, 345-353. https://doi.org/10.1111/j.0956-7976.2005.01538.x

Lee, D., \& Kim, K. (2017). Assessing healthcare service quality: a comparative study of patient treatment types. International Journal of Quality Innovation, 3. https://doi.org/10.1186/s40887-016-0010-5

Meier, K. J., Compton, M., Polga-Hecimovich, J., Song, M., \& Wimpy, C. (2019). Bureaucracy and the Failure of Politics: Challenges to Democratic Governance. Administration \& Society, 51(10), 1576-1605. https://doi.org/10.1177/0095399719874759

Nugroho, R. (2009). Public Policy (1st ed.). Elex Media Komputindo. https://opac.perpusnas.go.id/DetailOpac.aspx?id=706027

Paris, C., Colineau, N., Nepal, S., Bista, S., \& Beschorner, G. (2013). Ethical considerations in an online community: The balancing act. Ethics and Information Technology, 15. https://doi.org/10.1007/s10676-013-9315-4

Pernet, C. (2016). Null hypothesis significance testing: a short tutorial. F1000Research, 4, 621. https://doi.org/10.12688/f1000research.6963.3

Piligrimienè, Ž., Žukauskaitė, A., Korzilius, H., Banyte, J., \& Dovaliene, A. (2020). Internal and External Determinants of Consumer Engagement in Sustainable Consumption. Sustainability, 12, 1349. https://doi.org/10.3390/su12041349

Rahim, A. (2019). Governance and Good Governance-A Conceptual Perspective. Journal of Public Administration and Governance, 9, 133. https://doi.org/10.5296/jpag.v9i3.15417

Rian Andhika, L. (2017). Pathology Bureaucracy: Reality of the Indonesian Bureaucracy and Prevention. Jurnal Bina Praja, 9, 101-114. https://doi.org/10.21787/jbp.09.2017.101-114

Setyadiharja, R., Kurniasih, D., Nursnaeny, P., \& Nengsih, N. (2017). Good Governance vs Sound Governance: A Comparative Theoretical Analysis. https://doi.org/10.2991/icodag-17.2017.19

Timsal, A., \& Awais, M. (2016). Flexibility or ethical dilemma: an overview of the work from home policies in modern organizations around the world. Human Resource Management International Digest, 24, 12-15. https://doi.org/10.1108/HRMID03-2016-0027 
Višnjić, A., Veličković, V., \& Jović, S. (2012). Measures for Improving the Quality of Health Care. Acta Facultatis Medicae Naissensis, 2, 53-58. https://doi.org/10.2478/v10283-012-0008-4

Vizcarguenaga-Aguirre, I., \& López-Robles, J. R. (2020). Mono, mixed, or multiple strategies approach a descriptive study of the latest published articles in the International Journal of Project Management. 3rd International Conference on Research and Education in Project Management, 53(9), 1689-1699. 